\title{
SOSIALISASI MANAJEMEN PEMELIHARAAN SAPI POTONG GUNA MENINGKATKAN JUMLAH POPULASI, KUALITAS DAN NILAI JUAL
}

\author{
Sama' Iradat Tito, Della Aljanna Savita \\ Fakultas Matematika dan Ilmu Pengetahuan Alam, Universitas Islam Malang \\ *korespondensi email: sama_iradat_tito@unisma.ac.id
}

\begin{abstract}
ABSTRAK
Desa pagelaran merupakan salah satu desa yang ada di kecamatan Pagelaran yang memiliki beberapa dusun antara lain: dusun Sipring, dusun Krajan, dusun Sumbergempol dan Dusun Mentaraman.Dusun Sipring merupakan dusun yang ada didesa pagelaran dimana tim KSM-T melakukan pengabdian didusun Sipring dan berfokus antara RT 1-4. Didusun Sipring mayoritas masyarakat berprofesi sebagai peternak dan petani. Masyarakat RT 1-4 memiliki ternak kebanyakan sapi potong yang berjumlah 95 ekor sapi potong. Populasi tersebut terbagi atas sapi dara, pedet dan indukan sapi potong, sapi potong berjenis peranakan Limousin dengan sapi PO dan peranakan sapi PO dengan simental. Tetapi kebanyakan masyarakat tersebut belum banyak mengerti akan manajemen pemeliharaan sapi potong. Dengan adanya kegiatan sosialisasi ini diharapkan mampu memberikan sedikit pengetahuan untuk masyarakat guna memperbaiki nilai kualitas sapi potong tersebut yang nantinya akan dijual dipasaran dengan harga sebanding dengan kualitas tersebut. Ada 10\% masyarakat yang belum paham mengenai beberapa materi yang diberikan, 27\% paham dengan penyampaian materi dan 63\% masyarakat mampu memahami daripada materi yang diberikan. Jadi kegiatan ini dikatakan cukup berhasil karena lebih dari 50 persen masyarakat mampu menerima materi dengan baik.
\end{abstract}

Kata Kunci: manajemen pemeliharaan; sapi potong; sipring; sosialisasi

\section{PENDAHULUAN}

Kebutuhan daging sapi dari tahun ke tahun terus meningkat seiring dengan bertambahnya jumlah penduduk, peningkatan pendapatan dan kesejahteraan masyarakat serta semakin tingginya tingkat kesadaran masyarakat tentang pentingnya protein hewani. Di sisi lain penyediaan daging masih tergolong rendah apabila dibandingkan dengan permintaannya. Untuk mengurangi kesenjangan ini diperlukan berbagai upaya yang mampu meningkatkan produktivitas, terlebih pada peternak sapi potong rakyat (Nuryadi \& Wahyuningsih, 2011).

Berbagai masalah yang dihadapi peternak sapi potong selama ini dalam mendapatkan modal yang berasal dari lembaga keuangan formal, menyebabkan terhambatnya akselerasi penguatan skala usaha dan tidak berkembangnya sektor riil usaha peternakan sapi potong. Diperlukan skim pembiayaan (kredit) yang mampu mengakomodasi keperluan UMKM peternakan sapi potong yang memiliki karakteristik spesifik, seperti adanya siklus produksi yang menuntut kebijakan tenggang waktu angsuran awal dan penjadwalan angsuran kredit. Ketersediaan dan kemudahan pembiayaan dari perbankan akan sangat memacu percepatan sektor riil pada UMKM peternakan sapi potong sehingga akan meningkatkan populasi sapi 
potong dan menciptakan pemberdayaan ekonomi masyarakat di pedesaan (Sodiq, Suwarno, Fauziyah,, \& Wakhidati, 2017).

Desa pagelaran merupakan salah satu desa yang ada di kecamatan Pagelaran yang memiliki beberapa dusun antara lain: dusun Sipring, dusun Krajan, dusun Sumbergempol dan Dusun Mentaraman.Dusun Sipring merupakan dusun yang ada didesa pagelaran dimana tim KSM-T melakukan pengabdian didusun Sipring dan berfokus antara RT 1-4. Didusun Sipring mayoritas masyarakat berprofesi sebagai peternak dan petani. Masyarakat RT 1-4 memiliki ternak kebanyakan sapi potong. Setelah dilakukannya observasi mereka memiliki kendala seperti kurangnya kualitas sapi saat dijual dipasaran, nilai jual juga relative rendah dan produktivitas sapi potong yang sangat lambat. Maka dari itu kami selaku Tim KSM-T melakukan adanya sosialisasi manajemen pemeliharaan sapi potong.

Manajemen pemeliharaan sapi potong meliputi tiga sistem yaitu pemeliharaan secara intensif, pemeliharaan secara semi intensif dan pemeliharaan secara ekstensif. Pemeliharaan intensif paling sering digunakan di Indonesia, karena pemeliharaan sepenuhnya dilakukan di kandang. Sapi yang dipelihara secara intensif lebih efisien karena memperoleh perlakuan lebih teratur dalam hal pemberian pakan, pembersihan kandang, memandikan sapi (Sugeng,2000).

Menurut hasil survey dan observasi dusun Sipring mempunyai potensi besar untuk mengembangkan peternakan sapi tetapi sebagaiam masyarakat kurang pengetahuan akan manajemen pemeliharaan sapi potong sehingga hasilnya kurang memuaskan dan kualitas,harga pasar serta jumlah populasi menurun.Ada beberapa hal yang perlu diperhatikan saat sosialisasi dilaksanakan yakni memaparkan manajemen pemeliharaan, manajemen kandang ,manajemen pakan, Pemberian Bahan Kering, Kebutuhan Nutrien Sapi, Pentingnya pertambahan bobot harian, Konversi dan efisiensi pakan dan limbah hasil peternakan .

\section{METODE}

Pelaksanaan program Sosialisasi ini dilaksankan didusun Sipring RT 1-4 Desa Pagelaran,Kecamatan Pagelaran,Kabupaten Malang Jawa Timur pada tanggal 23 September 2021 dalam beberapa langkah. Langkah-langkah yang dilakukan sebagai berikut:

\section{Survey Lokasi}

Survey dilakukan pada tanggal 17 September didusun Sipring Pukul 09.00-12.00, survey dilakukan untuk mengetahui kondisi masyarakat dan kebutuhan masyarakat untuk kedepannya.

\section{Persiapan Materi}

Persiapan materi disusun oleh Tim KSM-Tematik Unisma dengan Materi manajemen pemeliharaan, manajemen kandang,manajemen pakan, Pemberian Bahan Kering, Kebutuhan Nutrien Sapi, Pentingnya pertambahan bobot harian, Konversi dan efisiensi pakan dan limbah hasil peternakan .

\section{Sosisalisasi}

Sosialisasi dilakukan Oleh Tim KSM-T Unisma dengan Melibatkan 44 orang peternak dilakukan dengan cara perkelompok ternak yang ditentukan oleh Tim KSM-T. Yang Masing-masing beranggotakan 11 orang peternak.

\section{Pengambilan data}

Pengambilan data dilakukan dengan cara observasi secara langsung dan menyebarkan kuisioner untuk peternak. Kemudian data tersebut akan diolah untuk dijadikan informasi valid.

\section{Analisis Data}

Analisis data pada sosialisasi ini diolah dengan Ms. Excel. 


\section{HASIL DAN PEMBAHASAN}

Pelaksanaan Program Pengabdian Masyarakat di Dusun Sipring,Desa Pagelaran Kecamatan Pagelaran, Kabupaten Malang ini dilakukan setelah pengamatan dan survey di lingkungan dusun Sipring.

Table 1 Jumlah Populasi Sapi Potong

\begin{tabular}{|c|c|c|c|c|}
\hline NO & Wilayah & Jenis & $\begin{array}{l}\text { Jumlah } \\
\text { Populasi }\end{array}$ & $\begin{array}{c}\text { Jumlah } \\
\text { Peternak }\end{array}$ \\
\hline \multirow{3}{*}{1} & DT 1 & Baby & 0 & \multirow{3}{*}{2} \\
\hline & K1 1 & Indukan & 3 & \\
\hline & & & 3 & \\
\hline \multirow{4}{*}{2} & & Baby & 8 & \multirow{4}{*}{31} \\
\hline & RT 2 & Dara & 12 & \\
\hline & & Indukan & 55 & \\
\hline & & & 75 & \\
\hline \multirow{4}{*}{3} & & Baby & 0 & \multirow{4}{*}{2} \\
\hline & RT 3 & Dara & 1 & \\
\hline & & Indukan & 1 & \\
\hline & & & 2 & \\
\hline \multirow{4}{*}{4} & & Baby & 2 & \multirow{4}{*}{10} \\
\hline & RT 4 & Dara & 6 & \\
\hline & & Indukan & 11 & \\
\hline & & & 19 & \\
\hline \multicolumn{3}{|c|}{$\begin{array}{l}\text { Jumlah Populasi dan } \\
\text { Peternak Keseluruhan }\end{array}$} & 97 & 45 \\
\hline
\end{tabular}

Dari hasil yang didapatkan populasi sapi yang ada di RT 1-4 berjumlah 97 ekor sapi yang berjenis sapi potong peranakan simental ongole dan peranakan sapi limousine, untuk jumlah populasi sapi di RT 1 berjumlah 3 ekor indukan yang dimiliki oleh 2 orang, Untuk RT 2 berjumlah 75 ekor yang terdiri 8 ekor pedet, 12 ekor sapi dara dan 55 indukan, pada RT 3 Terdapat 2 Sapi indukan dan Untuk RT 4 populasinya 19 sapi potong yang terdiri atas 2 pedet, 6 sapi dara dan 11 indukan sapi potong.

Manajemen pemeliharaan sapi potong meliputi tiga sistem yaitu pemeliharaan secara intensif, pemeliharaan secara semi intensif dan pemeliharaan secara ekstensif. Pemeliharaan intensif paling sering digunakan di Indonesia, karena pemeliharaan sepenuhnya dilakukan di kandang. Sapi yang dipelihara secara intensif lebih efisien karena memperoleh perlakuan lebih teratur dalam hal pemberian pakan, pembersihan kandang, memandikan sapi (Sugeng, 2000).

\section{Manajemen Kandang}

Table 2 Presentase Pemahaman Materi Manajemen Kandang

\begin{tabular}{|ccc|c|}
\hline Penilaian & Frekuensi & Persentase & Jumlah Peternak \\
\hline 25 & 0 & $0 \%$ & \\
50 & 1 & $2 \%$ & \\
75 & 4 & $9 \%$ & $\mathbf{4 5}$ \\
100 & 40 & $89 \%$ & \\
\hline Total & $\mathbf{4 5}$ & $\mathbf{1 0 0 \%}$ & \\
\hline
\end{tabular}


Dari hasil kuisioner yang dibagikan kepada responden atau peternak didapatkan hasil pemahaman yang sangat cukup untuk pembekalan manajemen kandang . didapatkan hasil 89\% sangat paham dengan frekuensi responden sejumlah 40 orang, untuk responden yang paham sejumlah 4 orang dengan presentase $9 \%$, dan kurang paham sejumlah 1 orang dengan presentase $2 \%$.

Kandang merupakan tempat tinggal sapi selama dalam tahap penggemukan. Kandang harus selalu dibersihkan setiap hari untuk menjaga sapi tetap sehat. Kandang yang baik tidak berdekatan dengan pemukiman, memiliki penanganan limbah dan ketersediaan air. Jarak kandang dengan pemukiman $100 \mathrm{~m}$, pembuangan limbah tersalurkan, persediaan air cukup dan jauh dari keramaian (Siregar, 2003). Kandang memiliki beberapa fungsi yaitu melindungi sapi,nyaman bagi ternak, lantai tidak licin mengurangi risiko ternak terluka, memudahkan pemeliharaan, terutama dalam pemberian pakan, minum dan mempermudah pengawasan kesehatan (Abidin, 2002).

\section{Pemberian Pakan}

Table 3 Presentase Pemahaman Materi Pemberian Pakan

\begin{tabular}{|ccc|c|}
\hline Penilaian & Frekuensi & Persentase & Jumlah Peternak \\
\hline 25 & 0 & $0 \%$ & \\
50 & 0 & $0 \%$ & \\
75 & 6 & $13 \%$ & 45 \\
100 & 39 & $87 \%$ & \\
\hline Total & 45 & $100 \%$ & \\
\hline
\end{tabular}

Dari materi pemberian pakan yang diberikan mendapatkan hasil pemahaman dari responden sebanyak 6 orang dengan presentase 13\% dengan penilaian paham dan sejumlah 39 orang dengan penilaian sangat paham. Hal ini terjadi karena peternak sering bertanya tentang pemberian pakan ternak pada mantri hewan daerah tersebut. Pakan merupakan biaya tertinggi dalam usaha peternakan, dengan adanya manajemen pemberian pakan yang baik dapat menekan biaya tersebut. Pemberian pakan bertujuan untuk memenuhi kebutuhan hidup sekaligus untuk pertumbuhan dan reproduksi. Sapi dalam masa pertumbuhan memerlukan pakan yang memadai baik dari segi kualitas maupun kuantitasnya (Djarijah, 1996).

\section{Produktivitas Indukan}

Table 4 Presentase Pemahaman Materi Produktivitas Indukan

\begin{tabular}{|c|cc|c|}
\hline Penilaian & Frekuensi & Persentase & jumlah Peternak \\
\hline 25 & 0 & $0 \%$ & 45 \\
50 & 1 & $2 \%$ & \\
75 & 7 & $16 \%$ & \\
100 & 37 & $82 \%$ & \\
\hline Total & 45 & $100 \%$ & \\
\hline
\end{tabular}

Dari pemaparan materi tersebut dapat ditarik kesimpulan bahwa ada 1 orang yang kurang paham mengenai materi tersebut dengan presentase $2 \%, 7$ orang memahami materi tersebut dengan presentase $16 \%$, dan 37 orang sangat memahami materi 
tersebut dengan presentase $82 \%$. Rata-rata hasil survey masyarakat menggunakan teknik inseminasi buatan untuk menambah populasi.

\section{Pengendalian Penyakit}

Table 5 Presentase Pemahaman Materi Pengendalian Penyakit
\begin{tabular}{|ccc|c|}
\hline Penilaian & Frekuensi & Persentase & Jumlah Peternak \\
\hline 25 & 0 & $0 \%$ & \\
50 & 3 & $7 \%$ & 45 \\
75 & 11 & $24 \%$ & \\
100 & 31 & $69 \%$ & \\
\hline Total & 45 & $100 \%$ & \\
\hline
\end{tabular}

Dari hasil pemaparan materi pengendalian penyakit ada 3 orang dengan presentase $7 \%$ yang kurang paham mater tersebut setelah diketahui alasannya hanya mereka menganggap sapi hanya bisa sakit panas dan flu tidak bisa sakit yang lain seperti organ reproduksi dan lain-lain.11 orang paham dengan materi tersebut dengan presentase $24 \%$ dan sangat paham terdapat 31 orang dengan presentase $69 \%$.

\section{Bahan Pakan}

Table 6 Presentase Pemahaman Materi Bahan Pakan

\begin{tabular}{|ccc|c|}
\hline Penilaian & Frekuensi & Persentase & Jumlah Peternak \\
\hline 25 & 0 & $0 \%$ & \\
50 & 0 & $0 \%$ & 45 \\
75 & 6 & $13 \%$ & \\
100 & 39 & $87 \%$ & \\
\hline Total & 45 & $100 \%$ & \\
\hline
\end{tabular}

Dari materi bahan pakan yang diberikan mendapatkan hasil pemahaman dari responden sebanyak 6 orang dengan presentase 13\% dengan penilaian paham dan sejumlah 39 orang dengan penilaian sangat paham. Sama dengan pemberian pakan warga sudah sedikit banyak tau tentang pakan untuk ternaknya. Jadi saat kuisioner dibagikan untuk kegiatan ini penyampaian cukup berhasil. Bahan pakan adalah bahan makanan yang diberikan kepada ternak untuk kelangsungan hidup, berproduksi dan berkembangbiak. Bahan pakan pada sapi potong adalah konsentrat dan hijauan. Konsentrat dapat berasal dari tanaman, kacang-kacangan dan umbi-umbian misalnya jagung, gandum, kedelai dan ubi kayu. Konsentrat juga dapat berasal dari hewan seperti tepung daging dan tepung ikan. Hijauan dapat berupa berupa rumput gajah, rumput raja, Indigofera sp dan lamtoro. Pakan sapi dapat disediakan dalam bentuk hijauan dan konsentrat (Sarwono,2002). Pemberian konsentrat sebaiknya terlebih dahulu kurang lebih 2 jam sebelum pemberian hijauan agar proses pencernaan berjalan optimal. Pemberian pakan dengan mengatur jarak waktu antara pemberian konsentrat dengan hijauan akan meningkatkan produksi (Syahwani, 2004). 


\section{TDN (Kebutuhan total digestible nutrients)}

Table 7 Presentase Pemahaman Materi TDN

\begin{tabular}{|ccc|c|}
\hline Penilaian & Frekuensi & Persentase & jumlah Peternak \\
\hline 25 & 0 & $0 \%$ & \\
50 & 9 & $20 \%$ & \\
75 & 17 & $38 \%$ & 45 \\
100 & 19 & $42 \%$ & \\
\hline Total & 45 & $100 \%$ & \\
\hline
\end{tabular}

Dari hasil pemaparan materi TDN terdapat 9 orang dengan presentase $20 \%$ yang kurang paham mengenai materi tersebut hal ini terjadi karena peternak yang minimnya pengetahuan, 17 orang paham dengan penyampaian materi presentase 38\% dan 19 orang sangat paham tentang materi tersebut. Materi tersebut sangat penting karena Total digestible nutrients (TDN) adalah jumlah total energi yang dikonsumsi dari pakan atau ransum, kekurangan energi dapat mengakibatkan bobot badan ternak menurun dan terhambat pertambahan bobot badan. Ransum harus memiliki keseimbangan antara protein dan energi yang baik, sehinggapertambahan bobot badan ternak akan meningkat (Tillman dkk., 1989). Tinggi rendahnya konsumsi TDN dipengaruhi oleh faktor bobot badan dan konsumsi pakan (Lubis, 1992).

\section{Pertambahan Bobot Harian}

Table 8 Presentase Pemahaman Materi Pertambahan Bobot Harian

\begin{tabular}{|ccc|c|}
\hline Penilaian & Frekuensi & Persentase & jumlah Peternak \\
\hline 25 & 0 & $0 \%$ & \\
50 & 6 & $13 \%$ & \\
75 & 21 & $47 \%$ & 45 \\
100 & 18 & $40 \%$ & \\
\hline Total & 45 & $100 \%$ & \\
\hline
\end{tabular}

Dari hasil pemaparan pertambahan bobot harian terdapat 6 orang yang kurang paham akan materi tersebut dengan presentase 13\%, 21 orang paham mengenai materi pertambahan bobot harian dengan presentase 47\%, dan sejumlah 18 orang sangat paham tentang materi tersebut dengan presentase $40 \%$. Pertambahan bobot harian ini sangat penting karena berpengaruh pada sapi yang nantinya akan dijual, jika bobot sapi semakin berat maka akan mahal juga harga sapi dipasaran.

\section{Konversi dan Efisiensi Pakan}

Table 9 Presentase Pemahaman Materi Konversi dan Efisiensi Pakan

\begin{tabular}{|ccc|c|}
\hline Penilaian & Frekuensi & Persentase & jumlah Peternak \\
\hline 25 & 0 & $0 \%$ & \\
50 & 1 & $2 \%$ & \\
75 & 7 & $16 \%$ & 45 \\
100 & 37 & $82 \%$ & \\
\hline Total & 45 & $100 \%$ & \\
\hline
\end{tabular}


Dari hasil materi yang dipaparkan ada 1 orang yang belum menguasai dan tidak tau tentang materi konversi pakan dengan presentase $2 \%$, sejumlah 7 orang paham dengan materi tersebut dengan presentase $16 \%$, dan sejumlah 37 orang sangat paham dengan materi tersebut dengan presentase 82\%. Materi ini sangat penting juga untuk menyeimbangkan antara hijauan dan pakan kering yang nantinya juga berpengaruh terhadap kualitas sapi yang akan dijual.

Konversi pakan adalah perbandingan atau rasio antar jumlah pakan yang dikonsumsi oleh ternak dengan produk yang dihasilkan oleh ternak. Konversi pakan dipengaruhi oleh kualitas pakan (Martawidjaja, 1998).Efisiensi pakan adalah perbandingan antara pertambahan bobot badan dengan jumlah pakan yang dikonsumsi. Efisiensi pakan merupakan perbandingan jumlah unit produk yang dihasilkan dengan jumlah unit konsumsi pakan dalam satuan waktu yang sama (Santosa, 1995).

\section{KESIMPULAN}

Dari hasil tersebut dapat disimpulkaan bahwa masih banyak masyarakat yang belum mengerti akan bagaimana perawatan dan manajemen sapi potong, jadi pada akhirnya sapi yang mereka panen seharusnya kualitasnya bisa melebihi dari biasanya sapi mereka tetap dengan kualitas standar. Dan pola pemeliharaan secara langsung dengan turun-temurun dari nenek moyang mereka, dengan adanya sosialisasi ini diharpakan mampu membangun mindset peternak dan mampu menerapkan ilmu ini yang bertujuan mensejahterkan masyarakat dan peternak didusun Siprinng terutama RT 1-4.

\section{UCAPAN TERIMA KASIH}

Ucapan terima kasih disampaikan kepada Lembaga Penelitian dan Pengabdian. kepada Masyarakat (LPPM), Universitas Islam Malang, yang telah memberikan kesempatan untuk dapat melakukan program pengabdian kepada masyarakat ini. Ucapan terima kasih juga disampaikan kepada warga dan segenap jajaran Pemerintah Desa Pagelaran, Kecamatan Pagelaran, Kabupaten Malang yang telah memberikan sambutan baik terhadap pelaksanaan berbagai kegiatan yang dilakukan.

\section{DAFTAR RUJUKAN}

Blakely, J., \& Bade, D. H. (1994). Ilmu Peternakan Cetakan Ke-4. Yogyakarta: UGM Press. Fikar, \& Ruhyadi. (2010). Buku Pintar Dan Bisnis Ternak Sapi Potong. Jakarta: Agromedia Pusat.

Hardjosubroto, W. (1994). Aplikasi Pemulih biakan Ternak Dilapangan. Jakarta: Grasindo. Soeparno. (1992). Imu dan Teknologi Daging. Yogyakarta: UGM Press.

Syamsul , F., \& Ruhyadi, D. (2012). Bisnis Penggemukan Sapi PT. Agromedia Pustaka. Jakarta Thomas, V.M.1991. Beef Cattle Production. Wafell and Press Montana University.USA. Jakarta: Jakarta Thomas.

Nuryadi , S., \& Wahyuningsih. (2011). Penampilan produksi Sapi Peranakan Ongole dan Peranakan Limousin di Kabupaten Malang. Jurnal Ternak Tropika, 12 (1) : 76-81 PSPK.

Sodiq, A., Suwarno, S., Fauziyah,, F. R., \& Wakhidati. (2017). Sistem produksi peternakan sapi potong di pedesaan dan strategi pengembangannya. Jurnal Agripet, 17(1), 60-66.

Syafrizal. (2011). Keragaman Genetik Sapi Persilangan Simmental di Sumatra Barat. Jurnal Embrio, Vol.4 , (1): 48-58. 